\title{
Does Value Co-creation impacts Customer Loyalty and Repurchase Intention?
}

\author{
Reema Frooghi ${ }^{1 *}$ \\ Zaki Rashidi ${ }^{2}$
}

\begin{abstract}
The study conducted is focused towards analyzing the association between value co-creation and its association towards customer satisfaction and ultimately customer loyalty driving towards customer's repurchase intention. The investigation is carried out among the young mobile phone users, the respondents being from the Private Universities of Karachi. The research utilizes path analysis to test the hypotheses and achieve the objectives of the research conducted. In total, 172 completed and usable questionnaires were received from respondents comprising of young university going mobile phone users. Convenience sampling was used selection of the sample. The results achieve via path analysis revealed that Customer Perceived Vale and Customer Trust positively impacts Co-creation of Value which results towards Customer Satisfaction and Customer Loyalty and ultimately customers repurchase intention. This research contributes significantly towards developing strategies for increasing satisfaction and loyalty pattern of the customer within the telecommunication industry of the country. This conducted research can further be replicated within other service sectors and also other age groups residing in the same service sector. The research conducted delivers an inimitable perspective of Value Co-creation in Pakistan Telecommunication sector which has been not much covered in the given geographic area. The model can be further used in understanding the consumer behavior in other service sector and also it can be applied on other age groups.
\end{abstract}

Keywords: Service-Dominant Logic, Customer Loyalty, Value Co-creation, Customer Satisfaction, Repurchase Intention, Customer Citizenship Behavior, Customer Participation Behavior and Service Sector of Pakistan.

1-PhD Scholar, Iqra University, email: reemafrooghi@yahoo.com

2- Director ORIC, Iqra University, email: zaki@iqra.edu.pk 
IBT Journal of Business Studies Volume 15(1), 2019

\section{INTRODUCTION}

The newly coined field of service logic is playing an influential role towards redefining the significant components of marketing. The significant notion inside this characterized field lies in value cocreation, the thought being that value isn't exclusively made for the customer by the provider of the service, however it is made for and by both the parties all through the service delivery process (Neghina, Caniels, Bloemer \& Birgelen, 2015; González-Mansilla, Berenguer-Contrí \& SerraCantallops, 2019). Value co-creation which has been developed as a broadly used term and a main thought within service marketing is a term being used to explain a change from organizations being definers of value towards a participative approach of both people \& organization developing and generating meaning (Alves \& Mainardes, 2017). For drawing a closer, longer and profitable relationship with the customers, managers are undertaking various creative approaches for energetic customer contribution in the service creation and the process of its delivery. The approach, as it is turning into the next frontier in competitive effectiveness, helps in achieving higher customer satisfaction \& customer loyalty, which is a competitive advantage for the organizations (Auh, Bell, McLeod \& Shih, 2007). Service-dominant (SD) logic model envisions customer as a value cocreator and a proactive creator rather than a passive receiver of value. It regards organizations as enablers rather than producer of value (Chen \& Wang, 2016).

Prahalad and Ramaswamy (2004) defines "co-creation as a combined creation between the organization and the customer, not as the organization who is trying to delight the customer, which has been elaborated as the customer to co-construct the service provision experience as per their need". Value co-creation not only motivates customer towards shared problem definition and solving but also builds an experiential milieu in which consumers experiences dynamic exchange relationship \& co-construct customized familiarities; product may be alike but customers can develop distinctive experiences. The present era related to service driven economy makes experience based \& customer centric approach elementary requirements for the growth of the service providers.

Companies for creation of values in new ways are both constrained and pulled in to make utilization of new service-based opportunities through redesign and reconfiguration of constellations of resources (Edvardsson, $\mathrm{Ng}$, Min, \& Firth, 2013). Current economic conditions make it critical for the companies to satisfy customers, as satisfied customers are crucial for organizational survival and stability (Pantouvakis \& Bouranta, 2013). Companies are trying hard to survive in severe competitive and cost-cutting forces (Duygun, 2015), which makes attempt of increasing market share linked with customer loyalty (Duygun, 2015).

There exist many different services; hospitals, transportation, infrastructure and expert services. These examples substantially differing from each other share common characteristics: every one of them depend on suppliers and clients cooperating for accomplishment of shared advantage (Peters et al., 2016). Marketers and researchers agree that service is a driving force in information systems discipline (Böhmann, Leimeister, \& Möslein, 2014). For understanding the real definition of service it is significant to comprehend the value creation process. Co-creation of value which is generated through actor-generated establishments exists within the mind of the individuals (Vargo \& Lusch, 2016), hence it is generated through context and cooperation, which helps to develop service in a process through alignment and customization of available organizational resources (Edvardsson, Tronvoll \& Gruber, 2011).

Organizational identification facilitates customers to partly encounter their self-definitional needs (Tuan, 2016; Tuan, 2018). This significance of identification leads to view the characteristics of a 
company as "representative" of film's resource-based outlook, for viewing the customers in process of re-defining their needs and roles with respect to their associations with company (Tuan, 2016). Well-known customers are not only completely loyal, as well as devotedly endorse the company \& its items and its services to other people (Bhattacharya \& Sen, 2003); and hence co-creates value for the organization (Tuan, 2016). Moreover, customers based on their discernment in regards to the high engaging quality of the organization, will, in general, build more commitment to the organization, by value co-creation behavior (Tuan, 2016; Tuan, 2018).

The subject of co-creation of value is in its earliest stages stage and it should be considered inside and out. It has made an alluring approach for the organizations for assortment of reasons; thoughts produced through co-creation are a nearby reflection of the consumers' needs. Therefore, it ends up fundamental for organizations to deal with this procedure productively to accomplish substantive competitive advantage (Prahalad \& Ramaswamy, 2004).

The primary motivation behind this examination is to find how value emerges for the customer and how the customer through a sense-production process builds their experience of value of a service co-op's interest is tended to, which results in the goal of the customer to not exclusively to devour the service again yet in addition to spread a positive word-of-mouth. A basic investigation of existing literature was carried out but there was no notable empirical study conducted in Pakistan that significantly measures the relationship of Customer Trust, Customer Perceived Value with Value co-creation which ultimately helps in achieving customer's satisfaction, customer loyalty and repurchase intention of the customer. Studies led proposes the system to be contemplated in various societies and geographic territories in order to make a superior comprehension of the model (Chan et al., 2010; Yi \& Gong, 2013; Edvardsson et al., 2013; Chen \& Wang, 2016). Moreover, an investigation on the precursors of the value co-creation behavior should be investigated and contemplated (Vega-Vazquez, Ángeles Revilla-Camacho, \& Cossío-Silva, 2013; Chen and Wang, 2016).

\section{Theoretical research framework}

The theoretical foundation used for the conducted study is social exchange theory, which was first introduced by (Homans, 1958). The theory's core concept is that behavior within exchange between individuals is determined by the rewards and drawbacks encountered during the interaction. That is, rewards in exchange tend to result in the other party providing rewards towards equilibrium. Gummesson and Mele (2010) clarify that co-production of value is derived from the amount for connection and the combination of assets. Integration assists to create exchange, asset exchanges and learning. In these intuitive procedures, members trade data as well as make their operant resources (learning and abilities) accessible and consequently cultivate new information and resources. Such members swap data and exchange assets to produce both unequivocal and implicit updated information through a consistent procedure of learning. Through this new way to deal with esteem, the advantages seen by buyers wind up coming to past those acquired from the dyadic connection among organizations and consumers, with the comparing requirement for starting to incorporate associations with different elements (e.g. different customers) also. The social exchange theory is constructed of three propositions: success, stimulus, and deprivation-satiation (Homans, 1958). The proposition that applies to this study is the success proposition. The success proposition involves rewards given throughout the process that encourage participation. Füller (2010) determined that rewards motivate some consumers to engage in co-creation of value and that consumers motivated by rewards have a greater skill level than consumers motivated by other factors. 
IBT Journal of Business Studies Volume 15(1), 2019

Based on the theory, and to the degree that S-D orientation give emphasis to shared benefit, we consequently forecast that organizations which are S-D-oriented are probable to build trust, generate high levels of perceived value, and inculcate affective commitment amongst their customers. The theoretical model established to study the association between Customer Trust, Customer Perceived Value, Value Co-creation on Customer Satisfaction \& Customer Loyalty which helps towards increasing repurchase intentions of the customers in depicted in Figure -1 .

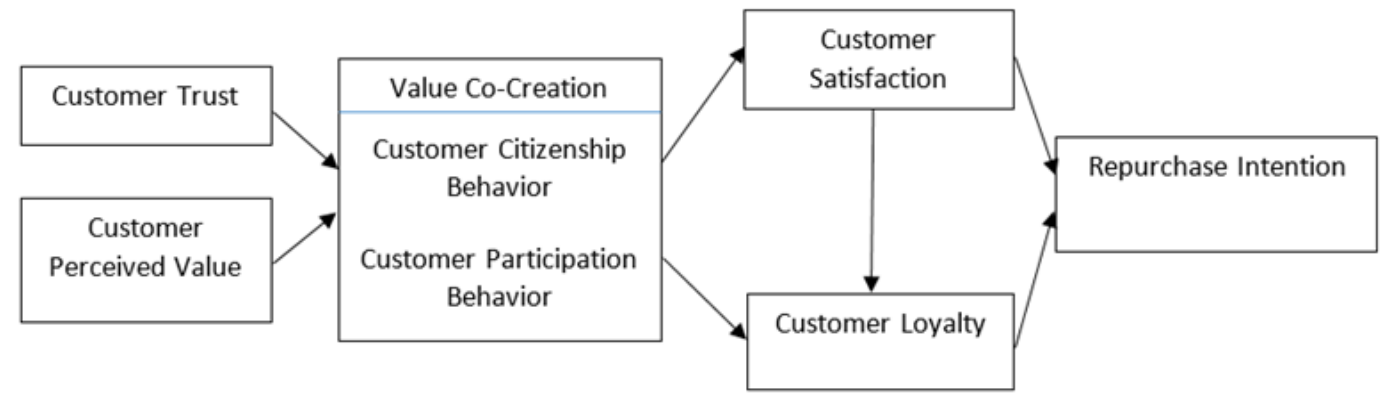

Figure 1: Conceptual Model

\section{Value co-creation}

Value co-creation has grown into a fundamental concept in the area of business management and service marketing (Saarijärvi et al., 2013; Yrjölä, Kuusela, Närvänen, Rintamäki \& Saarijärvi, 2019) and is being used extensively for defining a change in thoughts of the organizations as value definers towards a more participative process in which both customer and organizations collectively produce and improve significance (Ind \& Coates, 2013). Therefore, it is defined that novel vision of value cocreation behavior is reflective in the Service Dominant Logic Model (S-D Logic Model), reflecting value co-creation to be a shared creation procedure including both parties; the organization and the consumers (Prahalad \& Ramaswamy, 2004). In contrast to the traditional concept this defined approach to value differs in a way which identifies value construction done by the organization in their business structure and intended for the consumers (Vargo \& Lusch, 2004)

Co-creation which has initially been introduced by Prahalad and Ramaswamy (2004), through the acknowledgement of changing roles in marketing theatre, defining customer and supplier's interaction to be largely collaborated beyond the pricing system which is traditionally mediated through supply-demand relationship. Grounded on the perspective of service science (Vargo \& Lusch, 2004), organizations need not to focus on the products being offered, they need to focus on the offerings based on the services they can offer to their customers. Co-creation is generated through customer collaboration which facilitates in realizing the market offering and results in generation of requested benefits: services and activities (Galvagno \& Dalli, 2014).

In value co-creation, by contrast, value is co-created by the organization and consumer (Prahalad \& Ramaswamy, 2004) during interaction (Alves et al., 2016). Vargo and Lusch (2016) describe the intent of the original sixth foundational premise (that "Value is co-created by multiple actors, always including the beneficiary") was to recognize that the consumer is constantly intricate in their own value creation, but this does not imply that this is either individually or dyadic ally created. In Service-Dominant Logic this process of value co-creation instead acknowledges the multi-actor nature of the process and that value is generated through the incorporation of resources provided 
by many sources. From an organizational viewpoint, value co-creation when is harnessed and successfully managed as business logic (Alves et al., 2016), helps organizations to maximize the lifetime value of desirable consumers (Payne et al., 2008). Co-creation of value can highlight a consumer's opinion and enhance the process of identifying consumer's needs and wants (Lusch \& Vargo 2006). In some cases, this can help to develop new products (Alves et al., 2016). Value cocreation can be used as learning strategies for organizations to cope with market demands (Payne et al., 2008), establish valuable relationships with existing and potential consumers (Füller \& Bilgram, 2017), drive innovation processes and products (Edvardsson et al., 2013; Eletxigerra, Barrutia \& Echebarria, 2018), and result in benefits in the form of revenue, profit, and referrals for the organization (Payne et al., 2008).

Yi and Gong (2013) in their research conducted recommend two kinds of consumer co-creation behavior: consumer participation behavior defined as the in-role behavior desirable during successful and effective value co-creation behavior, and customer citizenship behavior defined as a intended, extra-role performance not essentially required for value co-creation but facilitates in bringing value addition for the organization. The author further elaborates that Customer Citizenship Behavior includes feedback (providing feedback and recommendations for improving of service being provided), tolerance (inclination to bear service failures), advocacy (suggesting the business to acquaintances) and helping (supporting other consumers).

\section{Customer trust}

Trust helps in cultivating a relationship between customer values as compared to those of the company (Alves \& Mainardes, 2017). According to Keh and Xie (2009), the involvements of growth among the relevant parties' foster exchange and contribute to relational commitment. Trust acts as an agreement towards the consistency and proficiency based on the enactment of the organization, confirming that the customers maintain to attain value from for the coming industrial associations with the similar service provider (Aurier \& N'Goala, 2010).

Value is a process of co-creation based on service-to-service interchange (Lusch \& Vargo, 2014) through the relationship of participants (Chandler \& Vargo, 2011). Value being a mutual task of the service delivery of manifold participants includes society, individual actors, or even a larger community (Lusch \& Vargo, 2014). It is through this interpersonal exchanges, which facilitates the actors to gain access towards consumption-related data holding minimum value (Brown, Broderick, $\&$ Lee, 2007). Trust is an essential agent that helps these systems or networks to perform accordingly.

Trust is regarded as one of the key aspects influencing the capacity for value creation by exchange process (Alves \& Mainardes, 2017). The significance of trust in service employees could be better understood if researchers agree to adopt the service-dominant logic for better understanding of customer involvement in usage and co-development of the desired service. Thus it has been hypothesized that:

H1: Customer Trust positively impacts Value Co-creation

\section{Customer perceived value}

Woodruff (1997) characterize perceived value of the customer as "a customer's apparent inclination for and assessment of those item qualities, trait exhibitions, and results emerging from utilize that encourage accomplishing the customer's objectives and purposes being used circumstances". It has also been defined as the relationship between the sacrifices and benefits experienced by a customer during the transaction taken place (Ulaga, 2003). 
Baron and Harris (2008) and Arnould et al. (2006) in their research conducted report that active engagement in consumer experience leads towards individuals to gain personal value through integration of cultural, physical and social resources into consumption experience as well as towards gaining of collective value through integration of operating resources within co-consumption of experience. Nambisan and Baron (2009) elaborates that perceived benefits of consumer; personal integration, learning, hedonism and social linkages have been defined as customer participation antecedents in value co-creation process within simulated settings. Likewise, Roberts et al. (2014) in their study conducted have proposed that perceived benefits acts as motivational factor for participation in activities related to co-creation. Thus it is hypothesized that:

H2: Customer Perceived Value positively impacts Value Co-creation

\section{Customer satisfaction}

Consumer satisfaction is a standout amongst the most imperative notions of the marketing literature, as it authorizes the connection between purchase and utilization processes with post-purchase phenomena, for example the change in state of mind, continue purchasing or loyalty towards a brand dedication (Vazquez, Camacho \& Silva, 2013). Customer satisfaction is regarded as an elementary factor towards achievement of goals of the organization, and is measured to be a not only a reference point standard of enactment but also a possible standard of quality of quality for an organization (Hussain et al., 2015; Frooghi et al., 2016). Companies have recognized that retention of actual customers is more profitable than acquiring new customers for replacing the lost ones (Boulter, 2013).

Hunt et al. (2012) examined co-creation of value and its effect on customer satisfaction with consumers of the produce section of a supermarket. This product, rather than service, based research revealed that satisfaction of customer with the product have been studied to have significantly positive relationship among those who had participated in co-creation of value along with the supplier. Participation in co-creation of value with an organization has a positively and significantly impact on the customers' satisfaction in both service and product-driven organizations. Therefore, it has been hypothesized that:

H3: Value co-creation positively impacts Customer Satisfaction.

\section{Customer loyalty}

Customer loyalty which is a key component of company's long term capability plays a vital role in consumer's marketing community (Chen \& Chen, 2010). Establishment of customer loyalty and retention of existing customers are thus critical task for service providers who are striving hard to gain competitive advantage (Chen \& Wang, 2016). Customer loyalty is a multifaceted construct due to the diverse coexisting factors in its conceptualization (Majumdar, 2005; Frooghi et al., 2016).

Grissemann and Stokburger-Sauer (2012) studied the association between company support for customer, customer value co-creation and its influence on satisfaction of the customer and customer loyalty. The research was led in a family-run travel agency of Austrian which is regarded to have strong connection with the customers. The results show a positive link among company support for customer and value co-creation by the customers. Furthermore, value co-creation behavior of the customers positively impacts customer satisfaction and customer loyalty. Hence, it has been hypothesized that:

H4: Value co-creation positively impacts Customer Loyalty. 
Attaining customer loyalty is regarded as basic goal of any organization. From the seller's perspective, the loyalty behavior of the customer appears as more prominent joint effort, less objections, less affectability to cost and, in whole, more noteworthy benefit of the customer (Callarisa, Bigne, Moliner \& García, 2009). Hence, customer loyalty is an essential factor for any firm in order to develop long term relationship. Study describing the relationship between customer satisfaction and co-creation of value is dominated by evaluation of customer satisfaction as an outcome of the results of co-creation of value.

H5: Customer Satisfaction positively impacts Customer Loyalty.

\section{Repurchase Intention}

Repurchase intention is referred as the aim of customer to retain a relationship with a given service provider for making a next purchase (Jones \& Taylor, 2007). As the cost obtaining a new customer is exceedingly greater than retaining an older one therefore, continued purchasing by a current customer is an important concern for the organization (Nikbin, Armesh, Heydari \& Jalalkamali, 2011). Repurchase expectation as a result of customer's satisfaction or dissatisfaction is a basic factor influencing customer's future association with an organization, its productivity, and in this way its business achievement (Nikbin, Armesh, Heydari \& Jalalkamali, 2011).

Dong, Evans and Zou (2008) studied the relationship between customer's intention to co-create and repurchase intention and found that variables of this study has a positive relationship. Park and Ha (2016) in their study conducted analyzed and explore a positive relationship among co-created value and customer's repurchase intention. Therefore, it is hypothesized that:

H6: Customer Satisfaction positively impacts Repurchase Intention

H7: Customer Loyalty positively impacts Repurchase Intention

\section{Hypothesized Model and Paths}

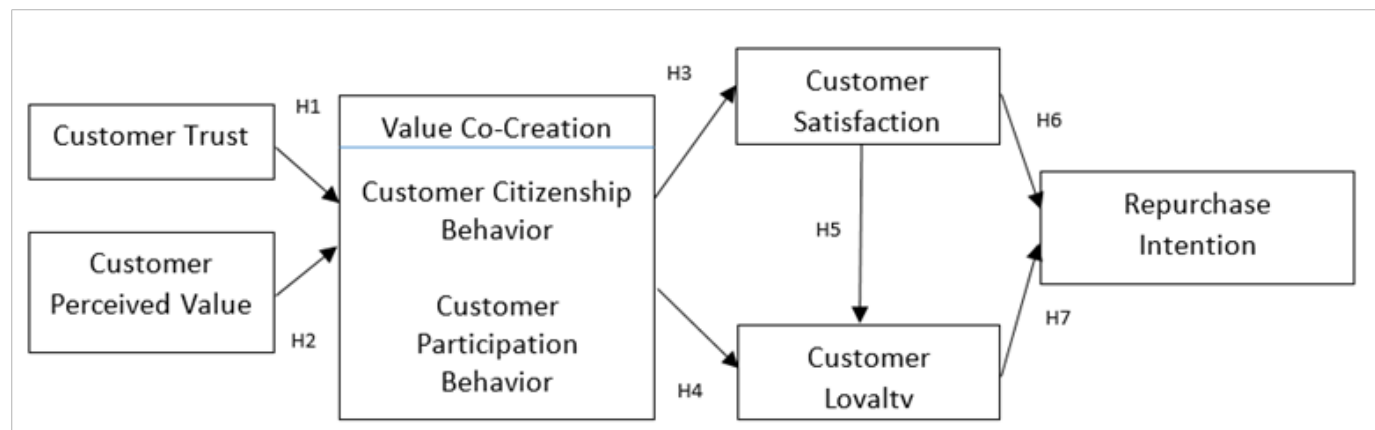

Figure 2: Hypothesized Model

\section{METHODOLOGY OF RESEARCH}

\section{Data Collection and Sampling Technique}

The research conducted utilizes 172 responses that has been gathered from university going students of Karachi through convenience sampling. The respondents include students who are mobile phone users. The sample has been gathered via primary source through the questionnaires by filling them from the respondents using both offline and online medium. The questionnaire has been sent to 225 respondents out of which 172 were received back. 
IBT Journal of Business Studies Volume 15(1), 2019

\section{Measures}

The questionnaire included 7 variables namely: Customer Trust, Customer Perceived Value, Customer Participation Behavior, Customer Citizenship Behavior, Customer Satisfaction, Customer Loyalty and Repurchase Intention.

\section{Value Co-Creation}

The measurement of Value Co-Creation was based on 2 dimensions namely: Customer Citizenship Behavior and Customer Participation Behavior. Items for Customer Participation Behavior has been extracted from Yi and Gong (2013), sample item includes "I accomplished all the required tasks". Items for Customer Citizenship Behavior has been extracted from Yi and Gong (2013), sample item includes "When I receive worthy service from the employee, I remark about it". 5-points Likert scale have been used to study the items of value co-creation whose range starts from 5 is to 1 ranging from strongly agree to strongly disagree.

\section{Customer Trust}

The items for Customer Trust have been extracted from Alves and Mainardes (2017). Sample item includes "I have faith on the guidance being provided by this organization and its employees". 5-points Likert scale have been used to measure the items of customer trust whose range starts from 5 is to 1 ranging from strongly agree to strongly disagree.

\section{Customer Perceived Value}

The items for Customer Perceived Value have been extracted from Alves and Mainardes (2017). Sample item includes "I receive higher quality services". 5-points Likert scale have been used to measure the items of customer perceived value whose range starts from 5 is to 1 ranging from strongly agree to strongly disagree.

\section{Customer Satisfaction}

The items for Customer Satisfaction have been extracted from Hennig-Thurau (2004). Sample item includes "I am completely gratified with the company". 5-points Likert scale have been used to measure the items of customer satisfaction whose range starts from 5 is to 1 ranging from strongly agree to strongly disagree.

\section{Customer Loyalty}

The items for Customer Loyalty have been extracted from Zeithaml, Berry and Parasuraman (1996). Sample item includes "Do more business with the organization in the next couple of years". 5-points Likert scale have been used to measure the items of customer loyalty whose range starts from 5 is to 1 ranging from strongly agree to strongly disagree.

\section{Repurchase Intention}

The items for repurchase intention have been extracted from Ramsey and Sohi (1997). Sample item includes "I am willing to discuss business with this company again". 5-points Likert scale have been used to measure the items of repurchase intention whose range starts from 5 is to 1 ranging from strongly agree to strongly disagree.

Sekaran (2016) suggested, the Cronbach $\alpha$ value of an instrument should be measured greater than 0.6; which depicts the reliability of the instrument. Thus for the given research reliability of each of the variable used for data collection was computed, and it was analyzed that all the computed figures are more than the recommended threshold point. The values of Cronbach $\alpha$ for the variables under study have been depicted in Table -1 .

Page $\mid 8$ 


\section{Descriptive Analysis and testing Assumptions of the Multivariate Outliers}

Data analysis has been conducted using SPSS 21 and AMOS 21. The conducted study sample size was $\mathrm{N}=172$. Table 2 explains the demographical structure of the collected data in the study.

\begin{tabular}{|c|c|c|c|}
\hline Variable Name & Adapted From & Cronbach Alpha & $\mathrm{CR}>0.7$ \\
\hline Customer Trust & $\begin{array}{l}\text { Alves \& Mainardes } \\
\text { (2017) }\end{array}$ & 0.812 & 0.814 \\
\hline $\begin{array}{c}\text { Customer Perceived } \\
\text { Value }\end{array}$ & $\begin{array}{c}\text { Alves \& Mainardes } \\
\text { (2017) }\end{array}$ & 0.833 & 0.846 \\
\hline $\begin{array}{c}\text { Customer Citizenship } \\
\text { Behavior }\end{array}$ & Yi \& Gong (2013) & 0.884 & 0.844 \\
\hline $\begin{array}{c}\text { Customer } \\
\text { Participation } \\
\text { Behavior }\end{array}$ & Yi \& Gong (2013) & 0.905 & 0.907 \\
\hline $\begin{array}{l}\text { Customer } \\
\text { Satisfaction }\end{array}$ & $\begin{array}{c}\text { Hennig-Thurau } \\
\text { (2004) }\end{array}$ & 0.839 & 0.842 \\
\hline Customer Loyalty & $\begin{array}{c}\text { Zeithaml, Berry \& } \\
\text { Parasuraman (1996) }\end{array}$ & 0.720 & 0.783 \\
\hline Repurchase Intention & $\begin{array}{c}\text { Ramsey \& Sohi } \\
\text { (1997) }\end{array}$ & 0.783 & 0.760 \\
\hline
\end{tabular}

Table 1: Variable, Cronbach Alpha and Composite Reliability

The conducted study structure includes age and gender category of the respondents. Also mobile service provider being used and the duration of usage are elaborated. So as to carry out the data analysis, initially, assumptions of SEM has been tested which includes; normality within the variables, sample size, outliers, multicollinearity and reliability of the scales (Hair et.al, 2006). As per study of Hair et al., (2006), for a research to be carried the sufficient sample size is considered to be between 50 to 400 observations. This study conducted has the sample size used is 172 which are acceptable as per the requirement given. For testing normality of the data set the standard range of Skewness and Kurtosis is required to fall between \pm 1 , which specifies a symmetric distribution of the data set (Fotopoulos \& Psomas, 2009). Table-2 indicates the descriptive statics of the study. For fulfilment of the assumptions of SEM, Univariate outliers within the data set has removed using mean method. 
IBT Journal of Business Studies Volume 15(1), 2019

\section{Gender}

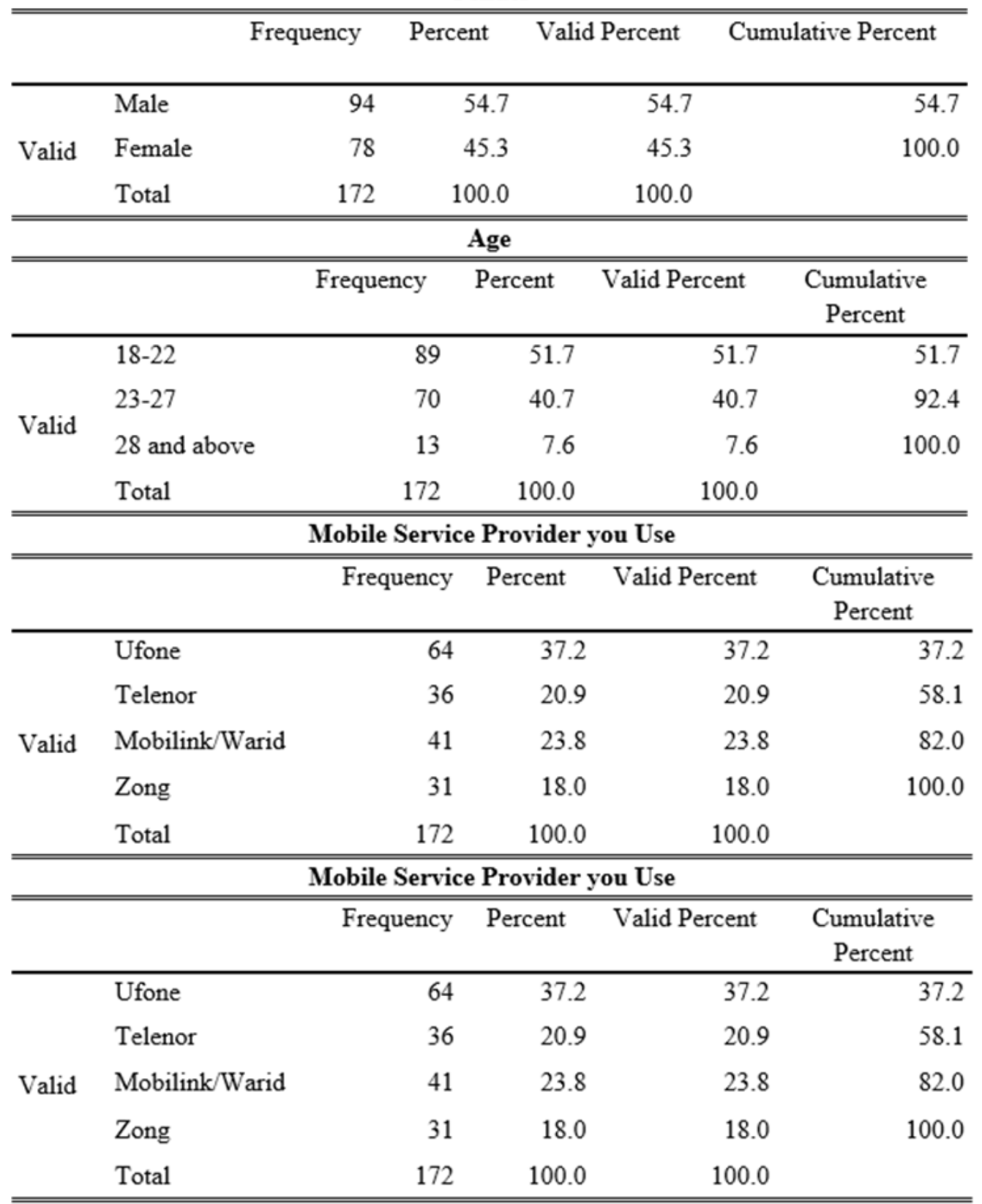

Table 2: Descriptive Analysis

\section{Exploratory Factor Analysis}

Exploratory Factor Analysis with Varimax has been implemented with the purpose of extraction of dimensions of constructs under study. Kaiser-Meyer-Olkin test of sampling adequacy has been computed to be 0.875 which is more than the required level i.e. 0.70 , depicting the sample size to be adequate for executing factor analysis (Barkus, Yavorsky, \& Foster, 2006). The Bartlet Test of 
Sphericity conducted for the study is also measured to be significant within the study (Chi-Square 5387.273, $\mathrm{df}=1326, \mathrm{p}<0.05$ ); depicting correlation among variables to be equal to zero (Leech et al., 2005). The 52 used items with the study explain $67.510 \%$ of total variance. The Rotated component matrix doesn't indicate any of the factor loading amongst the variables under analysis of the carried out study, which facilitates the existence of Discriminant validity. Discriminant validity has also been calculated and verified using Component Transformation Matrix; all the calculated values as suggested are less than the desired threshold range i.e. 0.70 (Tharenou, Donohue, \& Cooper, 2007) as depicted in Table-3.

\section{Confirmatory Factor Analysis}

The measurement model has been tested using AMOS21. The model contains 52 items that supports in explaining 7 variables specifically; Customer Perceived Value, Customer Trust, Customer Citizenship Behavior, Customer Participation Behavior, Customer Satisfaction, Customer Loyalty and Repurchase Intention. Table 1 represents the results of the construct, Cronbach Alpha value and value of Composite Reliability (CR). Moreover, the suggested criteria for composite reliability suggest that a scale is considered reliable if it has composite reliability value above 0.7 (Bagozzi \& $\mathrm{Yi}, 1988$ ); though, in our conducted research composite reliability is greater less than 0.7 for all the variables under study. The CFA model is defined as an estimate of linkage amongst observed and unobserved variables under study (Bryne, 2013). The Measurement model depend on the estimation of the given model fitness.

Table 3: Component Transformation Matrix

\begin{tabular}{|c|c|c|c|c|c|c|c|c|c|c|c|c|}
\hline Component & 1 & 2 & 3 & 4 & 5 & 6 & 7 & 8 & 9 & 10 & 11 & 12 \\
\hline$\overline{1}$ & .385 & .395 & .372 & .348 & .315 & .271 & .307 & .238 & .216 & .155 & .203 & .028 \\
\hline 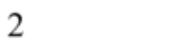 & -.527 & .162 & .479 & -.289 & .246 & .324 & -.062 & -.316 & -.042 & .244 & -.205 & .102 \\
\hline 3 & -.171 & -.402 & .130 & .491 & -.294 & .294 & -.395 & .221 & .230 & .333 & -.062 & -.068 \\
\hline 4 & -.285 & .408 & -.421 & .052 & .389 & -.220 & -.344 & 200 & .430 & .093 & -.110 & -.092 \\
\hline 5 & -.171 & -.238 & -.307 & -.015 & . 185 & .580 & .168 & .030 & .259 & -.502 & .094 & .302 \\
\hline 6 & .063 & -.310 & -.064 & -.396 & .095 & -.155 & .227 & . 420 & .126 & .477 & -.062 & .481 \\
\hline 7 & .171 & .248 & .052 & -.539 & -.322 & .376 & -.220 & .453 & .027 & -.112 & -.081 & -.313 \\
\hline 8 & .254 & -.327 & -.257 & -.162 & .478 & .254 & -.118 & -.191 & -.173 & .328 & .222 & -.454 \\
\hline 9 & -.423 & .151 & -.135 & .157 & .042 & .072 & .047 & .425 & -.641 & .058 & .388 & .045 \\
\hline 10 & .350 & .208 & -.259 & .170 & .051 & .255 & -.272 & -.083 & -.398 & .098 & -.506 & .408 \\
\hline 11 & .060 & .284 & -.219 & -.118 & -.375 & .132 & -.156 & -.372 & .170 & .297 & .571 & .300 \\
\hline 12 & -.177 & .146 & -.370 & .101 & -.286 & .184 & .620 & -.097 & .051 & .310 & -.317 & -.302 \\
\hline
\end{tabular}

Extraction Method: Principal Component Analysis.

Rotation Method: Varimax with Kaiser Normalization.

Comparative Fit index (CFI) is repeatedly stated model of fitness indices (McDonald \& Ho, 2002). Individually several indices are imperative meanwhile all denotes various aspects of model fitness (Crowley \& Fan, 1997). Kline (2005) for model fitness has strongly proposed the grouping of ChiSquare test, Comparative Fit Index (CFI) and RMSEA values. Such defined indices are ideal over other available indices as they are comparatively more insensitive to sample size, ambiguous and parameter estimates. Based on the recommendation given by Kline (2005), our final hypothesized model shows the goodness of fit indices which is depicted in Table -4 . 
IBT Journal of Business Studies Volume 15(1), 2019

\begin{tabular}{|c|c|c|c|c|}
\hline & CMIN / DF & TLI & CFI & RMSEA \\
\hline Recommended Value & $<5^{a}$ & $\geq 0.90^{b}$ & $\geq 0.90^{c}$ & $\leq 0.05^{d}$ \\
\hline Null Model & 4.546 & 0.000 & 0.000 & 0.144 \\
\hline One Factor Model & 4.546 & 0.000 & 0.000 & 0.144 \\
\hline Hypothesized Model ( $1^{\text {st }}$ Order) & 1.6 & 0.901 & 0.913 & 0.02 \\
\hline Hypothesized Model (2 $2^{\text {nd }}$ Order) & 1.597 & 0.913 & 0.923 & 0.05 \\
\hline
\end{tabular}

Table 4: Measurement of Model Fit (CFA and $2^{\text {nd }}$ Order CFA)

a = Bryne (2013), b = Hu and Bentler (1998), c = Bryne (1994), d = Steiger (1990)

For estimation of goodness-of-fit of the developed measurement model within the study, 4 common estimation methods have been utilized; CMIN/DF which has been suggested by Byrne (2013), CFI which has been suggested by Bryne (1994), TLI which has been suggested by Hu and Bentler (1998), and value of RMSEA which has been suggested by Steiger (1990). As depicted in Table-4 the estimated value of CMIN/DF value of CFA model (1st order) is estimated as 1.6, measured value of CFI is calculated to 0.913 , value of TLI is calculated to be 0.901 , and value of RMSEA is estimated to be calculated as 0.02 which is acceptable estimated values defined by several researchers.

Second order Confirmatory Factor Analysis model has been developed for the purpose of creating a new latent variable named Value Co-creation which describes the variables namely Customer Citizenship Behavior and Customer Participation behavior. The developed model was estimated for its goodness of fit, see table-4, Value of CMIN/DF of the model is calculated to be 1.597, value of TLI is calculated to be 0.913 , value of CFI is 0.923 and value of RMSEA of the given hypothesized model is calculated as 0.05 .

\section{Path Analysis and Hypothesis Testing}

Path analysis has been executed to analyze the significant impact of hypothesized regression paths. Byrne (2013) in his research conducted has emphasized that for studying that whether the hypothesized path is supported or not the value of C.R should be greater than \pm 1.96 . Hence, Table- 5 specifies the critical ratio, path coefficient of each path studied, standard error of each study path and significance value of each path under study; which supports to analyze and support the hypothesis.

The result indicates that Customer Trust has a significant and positive impact on Value Co-creation $\left(\beta=0.548^{* * *}\right)$. Customer Perceived Value have been studied to have significant and positive relationship with Value Co-creation $\left(\beta=0.193^{* *}\right)$. Value Co-creation has a positive and significant impact on Customer Satisfaction $\left(\beta=0.755^{* * *}\right)$ and Customer Loyalty $\left(\beta=0.206^{* *}\right)$. Furthermore, Customer Satisfaction have been studied to have a positive significant impact on Customer Loyalty $\left(\beta=0.776^{* * *}\right) \&$ Repurchase Intention $\left(\beta=0.246^{* * *}\right)$. Customer Loyalty having a positive significant impact on Repurchase Intention $\left(\beta=0.578^{* * *}\right)$. Table 5 depicts the hypothesized results. 


\begin{tabular}{|c|c|c|c|c|c|c|c|c|}
\hline Hypothesis & Hypot & thesize & d Path & Estimate & S.E. & C.R. & P-value & Remarks \\
\hline H1 & $\mathrm{VCC}$ & $<---$ & $\mathrm{CT}$ & .548 & .066 & 8.310 & $* * *$ & Supported \\
\hline $\mathrm{H} 2$ & $\mathrm{VCC}$ & $<--$ & CPV & .193 & .059 & 3.268 & .001 & Supported \\
\hline $\mathrm{H} 3$ & $\mathrm{CS}$ & $<---$ & VCC & .755 & .065 & 11.608 & $* * *$ & Supported \\
\hline $\mathrm{H} 4$ & $\mathrm{CL}$ & $<---$ & VCC & .206 & .067 & 3.091 & .002 & Supported \\
\hline H5 & $\mathrm{CL}$ & $<--$ & $\mathrm{CS}$ & .776 & .059 & 13.209 & $* * *$ & Supported \\
\hline H6 & RI & $<---$ & $\mathrm{CS}$ & .246 & .057 & 4.314 & $* * *$ & Supported \\
\hline $\mathrm{H} 7$ & RI & $<--$ & $\mathrm{CL}$ & .578 & .053 & 10.882 & $* * *$ & Supported \\
\hline
\end{tabular}

Table 5: Hypothesis Testing

\section{Discussion and Managerial Implications}

Value co-creation helps to achieve customer satisfaction and customer loyalty which facilitates in increasing long term relationship with the customer resulting in repurchase intention, supporting the research conducted by (Park \& Ha, 2016). For organizations to involve in the value co-creation process it is important to achieve customer trust and customer perceived value as it plays an important role in achieving organizational objectives. The research conducted advocates the importance of the relationship between customer trust, customer perceived value, value co-creation behavior and its result on customer satisfaction, customer loyalty and ultimately customer repurchase intention.

Through prominence of value co-creation in the marketing literature, the present study sheds light on the importance of value co-creation and how the telecommunication industry within Pakistan can benefit by incorporating such marketing strategies. Furthermore, the study will help the telecommunication industry to develop strategies for increased acceptance in the telecommunication sector. As customers are becoming more knowledgeable, value co-creation helps the companies to look into the areas that are important for the customers.

The telecommunication sector of Pakistan should increase their focus on retention of the customer which is a resultant of customer satisfaction and customer loyalty through value co-creation behavior. Companies should also need to analyze that how customer trust and their perceived value help in achieving customer retention.

\section{Research Limitations and Further Area of Study}

Though, the study helps to establish a comprehensive analysis on value co-creation behavior within telecommunication sector; further area of research can be focused on other service sectors of Karachi. Secondly, Customer Trust and Customer Perceived Value have been studied as antecedents of value co-creation behavior; whereas further research can investigate other antecedents of value co-creation behavior. Thirdly, the conducted research is focused towards young mobile users within Karachi area. Further research can be therefore conducted focusing on other geographic regions and also on other age groups. 
IBT Journal of Business Studies Volume 15(1), 2019

\section{REFERENCES}

Alves, H., \& Wagner Mainardes, E. (2017). Self-efficacy, trust, and perceived benefits in the cocreation of value by consumers. International Journal of Retail \& Distribution Management, 45(11), 1159-1180.

Alves, H., Fernandes, C., \& Raposo, M. (2016). Value co-creation: Concept and contexts of application and study. Journal of Business Research, 69(5), 1626-1633.

Arnould, E. J., Price, L. L., \& Malshe, A. (2006). Toward a cultural resource-based theory of the customer. The service-dominant logic of marketing: Dialog, debate and directions, 34(3), 320333.

Auh, S., Bell, S. J., McLeod, C. S., \& Shih, E. (2007). Co-production and customer loyalty in financial services. Journal of retailing, 83(3), 359-370.

Aurier, P., \& N'Goala, G. (2010). The differing and mediating roles of trust and relationship commitment in service relationship maintenance and development. Journal of the Academy of Marketing Science, 38(3), 303-325.

Bagozzi, R. P., \& Yi, Y. (1988). On the evaluation of structural equation models. Journal of the academy of marketing science, 16(1), 74-94.

Barkus, E., Yavorsky, C., \& Foster, J. (2006). Understanding and Using Advanced Statistics. Faculty of Health \& Behavioural Sciences-Papers, 393.

Baron, S., \& Harris, K. (2008). Consumers as resource integrators. Journal of marketing Management, 24(1-2), 113-130.

Bhattacharya, C. B., \& Sen, S. (2003). Consumer-company identification: A framework for understanding consumers' relationships with companies. Journal of marketing, 67(2), 76-88.

Böhmann, T., Leimeister, J. M., \& Möslein, K. (2014). Service-systems-engineering. Wirtschaftsinformatik, 56(2), 83-90.

Boulter, J. (2013). How to build profitable customer relationships. Retrieved January, 7, 2015.

Brown, J., Broderick, A. J., \& Lee, N. (2007). Word of mouth communication within online communities: Conceptualizing the online social network. Journal of interactive marketing, 21(3), 2-20.

Byrne, B. M. (1994). Structural equation modeling with EQS and EQS/Windows: Basic concepts, applications, and programming. Sage.

Byrne, B. M. (2013). Structural equation modeling with EQS: Basic concepts, applications, and programming. Routledge.

Callarisa Fiol, L. J., Bigne Alcaniz, E., Moliner Tena, M. A., \& García, J. S. (2009). Customer loyalty in clusters: perceived value and satisfaction as antecedents. Journal of Business-toBusiness Marketing, 16(3), 276-316.

Chan, K. W., Yim, C. K., \& Lam, S. S. (2010). Is customer participation in value creation a double-edged sword? Evidence from professional financial services across cultures. Journal of marketing, 74(3), 48-64.

Chandler, J. D., \& Vargo, S. L. (2011). Contextualization and value-in-context: How context frames exchange. Marketing theory, 11(1), 35-49.

Chen, C. F., \& Chen, F. S. (2010). Experience quality, perceived value, satisfaction and behavioral intentions for heritage tourists. Tourism management, 31(1), 29-35.

Chen, C. F., \& Wang, J. P. (2016). Customer participation, value co-creation and customer loyalty-A case of airline online check-in system. Computers in Human Behavior, 62, 346-352.

Crowley, S. L., \& Fan, X. (1997). Structural equation modeling: Basic concepts and applications in personality assessment research. Journal of personality assessment, 68(3), 508-531.

Dong, B., Evans, K. R., \& Zou, S. (2008). The effects of customer participation in co-created service 
recovery. Journal of the academy of marketing science, 36(1), 123-137.

Duygun, A. (2015). The impacts of customer loyalty on negative word-of-mouth communication and repurchase intention. Journal of Marketing and Management, 6(1), 16.

Edvardsson, B., Ng, G., Min Choo, Z., \& Firth, R. (2013). Why is service-dominant logic based service system better? International Journal of Quality and Service Sciences, 5(2), 171-190.

Edvardsson, B., Tronvoll, B., \& Gruber, T. (2011). Expanding understanding of service exchange and value co-creation: a social construction approach. Journal of the Academy of Marketing Science, 39(2), 327-339.

Eletxigerra, A., Barrutia, J. M., \& Echebarria, C. (2018). Place marketing examined through a service-dominant logic lens: A review. Journal of Destination Marketing \& Management, 9, $72-84$.

Fotopoulos, C. B., \& Psomas, E. L. (2009). The impact of "soft" and "hard" TQM elements on quality management results. International Journal of Quality \& Reliability Management, 26(2), 150-163.

Frooghi, R., Afshan, S., \& Waseem, S. N. (2016) The Integration of Loyalty, Satisfaction, and Relationship Commitment Models to Predict Customer Retention in Pakistani Telecom Sector, South Asian Journal of Management Sciences, 10(2), 56-79.

Füller, J. (2010). Refining virtual co-creation from a consumer perspective. California management review, 52(2), 98-122.

Füller, J., \& Bilgram, V. (2017). The moderating effect of personal features on the consequences of an enjoyable co-creation experience. Journal of Product \& Brand Management, 26(4), 386-401.

Galvagno, M., \& Dalli, D. (2014). Theory of value co-creation: a systematic literature review. Managing Service Quality, 24(6), 643-683.

González-Mansilla, Ó., Berenguer-Contrí, G., \& Serra-Cantallops, A. (2019). The impact of value co-creation on hotel brand equity and customer satisfaction. Tourism Management, 75, 51-65.

Grissemann, U. S., \& Stokburger-Sauer, N. E. (2012). Customer co-creation of travel services: The role of company support and customer satisfaction with the co-creation performance. Tourism Management, 33(6), 1483-1492.

Gummesson, E., \& Mele, C. (2010). Marketing as value co-creation through network interaction and resource integration. Journal of Business Market Management, 4(4), 181-198.

Hair Jr, J. F., Black, W. C., Babin, B. J., Anderson, R. E., \& Tatham, R. (2006). Multivariate data analysis. Prentice Hall, New Jersey.

Hennig-Thurau, T. (2004). Customer orientation of service employees: Its impact on customer satisfaction, commitment, and retention. International Journal of Service Industry Management, 15(5), 460-478.

Homans, G. C. (1958). Social behavior as exchange. American journal of sociology, 63(6), 597-606.

Hu, L. T., \& Bentler, P. M. (1998). Fit indices in covariance structure modeling: Sensitivity to under parameterized model misspecification. Psychological methods, 3(4), 424.

Hunt, D. M., Geiger-Oneto, S., \& Varca, P. E. (2012). Satisfaction in the context of customer coproduction: a behavioral involvement perspective. Journal of Consumer Behaviour, 11(5), 347356.

Hussain, R., Al Nasser, A., \& Hussain, Y. K. (2015). Service quality and customer satisfaction of a UAE-based airline: An empirical investigation. Journal of Air Transport Management, 42, 167-175.

Ind, N., \& Coates, N. (2013). The meanings of co-creation. European Business Review, 25(1), 8695.

Jones, T., \& Taylor, S. F. (2007). The conceptual domain of service loyalty: how many dimensions?. Journal of Services Marketing, 21(1), 36-51. 
IBT Journal of Business Studies Volume 15(1), 2019

Keh, H. T., \& Xie, Y. (2009). Corporate reputation and customer behavioral intentions: The roles of trust, identification and commitment. Industrial marketing management, 38(7), 732-742.

Kline, R. B. (2005). Methodology in the social sciences.

Leech, N., Barrett, K., \& Morgan, G. A. (2013). SPSS for intermediate statistics: Use and interpretation. Routledge.

Lusch, R. F., \& Vargo, S. L. (2006). Service-dominant logic: reactions, reflections and refinements. Marketing theory, 6(3), 281-288. M. Brady, J. Cronin, T. Hult, "Assessing the effects of quality, value, and customer satisfaction on consumer behavioral intentions in service environments". Journal of Retailing, Vol. 76, No. 2, 2009, 193-218.

Lusch, R. F., \& Vargo, S. L. (2014). The service-dominant logic of marketing: Dialog, debate, and directions. Routledge.

Majumdar, A. (2005). A model for customer loyalty for retail stores inside shopping malls-an Indian perspective. Journal of Services Research, 27(1), 5-21.

McDonald, R. P., \& Ho, M. H. R. (2002). Principles and practice in reporting structural equation analyses. Psychological methods, 7(1), 64.

Nambisan, S., \& Baron, R. A. (2009). Virtual customer environments: testing a model of voluntary participation in value co-creation activities. Journal of product innovation management, 26(4), 388-406.

Neghina, C., Caniëls, M. C., Bloemer, J. M., \& van Birgelen, M. J. (2015). Value cocreation in service interactions: Dimensions and antecedents. Marketing Theory, 15(2), 221-242.

Nikbin, D., Armesh, H., Heydari, A., \& Jalalkamali, M. (2011). The effects of perceived justice in service recovery on firm reputation and repurchase intention in airline industry. African journal of business Management, 5(23), 9814-9822.

Pantouvakis, A., \& Bouranta, N. (2013). The link between organizational learning culture and customer satisfaction: Confirming relationship and exploring moderating effect. The Learning Organization, 20(1), 48-64.

Park, J., \& Ha, S. (2016). Co-creation of service recovery: Utilitarian and hedonic value and postrecovery responses. Journal of Retailing and Consumer Services, 28, 310-316.

Payne, A. F., Storbacka, K., \& Frow, P. (2008). Managing the co-creation of value. Journal of the academy of marketing science, 36(1), 83-96.

Peters, C., Maglio, P., Badinelli, R., Harmon, R. R., Maull, R., Spohrer, J. C., \& Griffith, T. L. (2016). Emerging digital frontiers for service innovation. Communications of the Association for Information Systems: CAIS, 39, online.

Prahalad, C. K., \& Ramaswamy, V. (2004). Co-creation experiences: The next practice in value creation. Journal of interactive marketing, 18(3), 5-14.

Ramsey, R. P., \& Sohi, R. S. (1997). Listening to your customers: The impact of perceived salesperson listening behavior on relationship outcomes. Journal of the Academy of marketing Science, 25(2), 127-137.

Roberts, D., Hughes, M., \& Kertbo, K. (2014). Exploring consumers' motivations to engage in innovation through co-creation activities. European Journal of Marketing, 48(1/2), 147-169.

Saarijärvi, H., Kannan, P. K., \& Kuusela, H. (2013). Value co-creation: theoretical approaches and practical implications. European Business Review, 25(1), 6-19.

Sekaran, U., \& Bougie, R. (2016). Research methods for business: A skill building approach. John Wiley \& Sons.

Steiger, J. H. (1990). Structural model evaluation and modification: An interval estimation approach. Multivariate behavioral research, 25(2), 173-180.

Tharenou, P., Donohue, R., \& Cooper, B. (2007). Management research methods (p. 338). Melbourne: Cambridge University Press.

Page | 16 
Tuan, L. T. (2016). How HR flexibility contributes to customer value co-creation behavior. Marketing Intelligence \& Planning, 34(5), 646-670.

Tuan, L. T. (2018). Behind the influence of job crafting on citizen value co-creation with the public organization: joint effects of paternalistic leadership and public service motivation. Public Management Review, 20(10), 1533-1561.

Ulaga, W. (2003). Capturing value creation in business relationships: A customer perspective. Industrial marketing management, 32(8), 677-693.

Vargo, S. L., \& Lusch, R. F. (2004). Evolving to a new dominant logic for marketing. Journal of marketing, 68(1), 1-17.

Vargo, S. L., \& Lusch, R. F. (2016). Institutions and axioms: an extension and update of servicedominant logic. Journal of the Academy of Marketing Science, 44(1), 5-23.

Vega-Vazquez, M., Ángeles Revilla-Camacho, M., \& J. Cossío-Silva, F. (2013). The value cocreation process as a determinant of customer satisfaction. Management Decision, 51(10), 1945-1953.

Woodruff, R. B. (1997). Customer value: the next source for competitive advantage. Journal of the academy of marketing science, 25(2), 139.

Yi, Y., \& Gong, T. (2013). Customer value co-creation behavior: Scale development and validation. Journal of Business Research, 66(9), 1279-1284.

Yrjölä, M., Kuusela, H., Närvänen, E., Rintamäki, T., \& Saarijärvi, H. (2019). Leading Change: A Customer Value Framework. Leading Change in a Complex World: Transdisciplinary Perspectives.

\section{Appendix - Measured Items}

\section{Customer Trust}

I believe that I can trust this organization and its employees for solving my problems.

I am confident that the organization and its employees will properly provide the service.

I trust the advice that is provided by this organization and its employees.

I believe this organization and its employees are concerned regarding my needs.

\section{Customer Perceived Value}

I obtain higher quality service.

I obtain more customized services.

I receive fewer service failure.

I receive an improvised relationship with the organization.

I obtain a more pleasant employee interaction.

I attain special treatment from the organization.

\section{Customer Citizenship Behavior}

If I have a useful idea on how to improvise the service, I let the employee know.

When I receive worthy service from the employee, I remark about it.

When I experience a problem, I let the employee know about it.

I said positive things about the organization and the employee to others.

I recommended the organization and the employee to others.

I encouraged friends and relatives to use services of the organization.

I assist other customers if they need my help.

I help other customers if they seem to have problems.

I teach other customers to use the service correctly. 
IBT Journal of Business Studies Volume 15(1), 2019

I give advice to other customers.

If service is not delivered as expected, I would be willing to put up with it.

If the employee makes a mistake during service delivery, I would be willing to be patient.

If I have to wait longer than I normally expected to receive the service, I would be willing to adapt.

\section{Customer Participation Behavior}

I have inquired others for information on what this organization has to offer.

I have explored for information on where the organization is located.

I have paid attention to how others act to use the organization's service.

I have always clearly clarified what I wanted the employee to do.

I gave the employee accurate information.

I provided essential information so that the employee could perform his/her responsibilities.

I answered all the employee's service-related questions.

I performed all the tasks that are necessary.

I adequately accomplished all the expected behaviors.

I fulfilled responsibilities to the organization.

I followed the employee's directives/orders.

I was friendly to the employee.

I was kind to the employee.

I was polite to the employee.

I was courteous to the employee.

I didn't act offensively to the employee.

\section{Customer Satisfaction}

I am fully satisfied with the company.

The company always fulfils my expectations.

The company has never disappointed me so far.

My experience with the company is excellent.

\section{Customer Loyalty}

Say positive things about the organization I use to other people.

Recommend the organization to someone who seeks my advice.

Encourage friends and relatives to do avail the service of this organization.

Consider the organization the first choice to use services from.

Do more business with the organization in the next few years.

\section{Repurchase Intention}

It is probable that I will contact with this company again.

I am willing to discuss business with this company again.

I plan to continue doing business with this company.

I will purchase from this company again. 